\title{
The Impacts of Green Credit on the Financial Performance and Risks of Chinese SMEs-Taking BOSSCO as an Example
}

\author{
Qianyang Zhang \\ Department of Finance, Business School, Hohai University, Nanjing, China \\ Email: hx_class2zhqy@163.com
}

How to cite this paper: Zhang, Q.Y. (2018) The Impacts of Green Credit on the Financial Performance and Risks of Chinese SMEs-Taking BOSSCO as an Example. Open Access Library Journal, 5: e4892.

https://doi.org/10.4236/oalib.1104892

Received: September 7, 2018

Accepted: October 21, 2018

Published: October 24, 2018

Copyright $\odot 2018$ by author and Open Access Library Inc.

This work is licensed under the Creative Commons Attribution International License (CC BY 4.0). http://creativecommons.org/licenses/by/4.0/

\section{Open Access}

\begin{abstract}
China's green finance is gradually developing and prospering under the impetus of the government. Green credit is one of the main manifestations of green finance, whose goal is to adjust the bank's credit structure. Its main audience is environmentally friendly SMEs. Many scholars have studied the changes and potential risks that green credit may bring to bank performance, but only a small number of people have explored the impact that green credit may have on SMEs. Taking BOSSCO as an example, this paper uses DuPont analysis to explore the impacts and risks that green credit may have on the performance of Chinese SMEs.
\end{abstract}

\section{Subject Areas}

Corporate Governance

\section{Keywords}

Green Credit Chinese SMEsDuPont Analysis

\section{Introduction}

Green credit originated from green finance and was proposed according to national environmental economic policies and industrial policies. It refers to policy banks and other financial institutions providing low-interest loans to enterprises with environmentally friendly production facilities, ecological protection and construction projects etc., imposing access restrictions and implementing punitive high interest rates on contaminated companies and projects. Its main purpose is to appropriately divest credit funds from companies and projects that have a negative impact on the environment, thereby achieving a "green alloca- 
tion" of funds.

In recent years, China has been continuously exploring the way to achieve environmental protection through financial development and adjustment of its economic structure. In July 2007, the State Environmental Protection Administration, the People's Bank of China, and the China Banking Regulatory Commission jointly issued the "Opinions on Implementing Environmental Protection Policies and Regulations to Prevent Credit Risks", marking the green economy as an economic tool to fully enter China's main battlefield for pollution reduction. Subsequently, the regulatory authorities issued a series of documents to guide the development of green credit in China. On February 24, 2012, the China Banking Regulatory Commission issued a green credit guide, first guiding the development of green credit in the banking sector.

It can be seen that the Chinese government is steadily promoting the implementation of green credit and improving the credit structure of banks. Looking at the current literature on the study of green credit, most of them are discussing the performance changes and risks brought by green credit to banks. However, there are few articles on the impact of green credit on enterprises. SMEs (Small and Medium-sized Enterprises) are the main customers of green credit, and the promotion of green credit has increased the financing channels for SMEs. But at the same time, in order to meet the conditions of green credit, SMEs must make some production or production process changes, which may bring certain risks to enterprises. Due to small scale and imperfect financial systems of SMEs, their abilities of taking risks are very limited. Therefore, it is very practical to study the impacts of green credit on Chinese SMEs. Through the case of BOSSCO, this paper analyzes the possible impacts and risks of green credit on corporate financial performance.

\section{Literature Review}

Jeucken (2001) proposed that the management pressure of environmental risks comes from two aspects, one is external, including pressure from the government, the pressure of consumers and competitors, and the internal pressure from employees, customers and policies [1]. Schaltegger and Figge (2001) proposed that environmental risk management of commercial banks can reduce non-performing assets, reduce internal operating costs, improve operational efficiency, and can be used as a new business opportunity to develop new financial innovation products [2].

Sabine K Mc Neill (2007) proposed a model of "green credit", rather than an environmental tax, to guide the whole society to transform production methods into sustainable development. Energy-efficient buildings, energy-efficient energy, energy-efficient transportation, and the use of renewable energy can all be developed by relying on the development of "green credit" [3].

The theoretical research of Duan and Niu (2010) shows that the probability distribution of green credit to government, financial institutions and enterprises is demonstrated from the perspective of game theory [4]. Lin Jun (2006) analyzes 
the status and characteristics of the development of SMEs in the UK, and explains the development of SMEs in the UK in terms of credit business and fiscal policy [5].

\section{Analysis Method: DuPont Analysis}

DuPont Analysis uses a relationship between several major financial ratios to comprehensively analyze a company's financial situation. Specifically, it is a classic method used to evaluate a company's profitability and return on equity, and to evaluate corporate performance from a financial perspective. The DuPont analysis helps managers to more clearly see the determinants of the basic rate of return on equity, as well as the correlation between net sales profit and total asset turnover and debt ratio. It provides managers with a clear picture to examine the efficiency of the company's asset management and whether it maximizes the return on investment of shareholders.

\section{The Application of DuPont Analysis}

BOSSCO (stock code: 300422) was established in 1999 and listed on the Shenzhen GEM (Growth Enterprise Market) in 2015. It is headquartered in Guangxi, China and has a number of molecular companies and service organizations at home and abroad. Its business areas focus on water treatment, ecological restoration, clean production, solid waste treatment, atmospheric treatment, new energy and green product development. BOSSCO's service scope covers environmental protection industry chain such as engineering consulting design, research and development, equipment manufacturing, engineering construction, facility operation, investment and financing operations.

BOSSCO is listed on the GEM and is the representative of China's innovative SMEs. China Merchants Bank Nanning Branch and BOSSCO established a green credit relationship in 2015. China Merchants Bank Nanning Branch acts to provide liquidity loan credit, electronic commercial draft acceptance and other business support to promote the development of environmental protection. The following, we will use DuPont analysis to analyze the changes in the financial performance of BOSSCO after accepting green credit.

From Table 1, in general, BOSSCO's ROE (Rate of Return on Equity) has first dropped and then risen since 2015. This shows that after accepting green credit, the company's ability to obtain net income from its own capital has been affected in the short term. The Net Profit Margin on Sales rose first and then fell. Due to the particularity of its environmental protection enterprises, the increase in short-term funds of enterprises has also improved the level of profit from sales revenue. The Total Asset Turnover rate is declining, indicating that the efficiency of the use of assets has declined. The EM (Equity Multiplier) first increased and then reduced, indicating its financial leverage increased and then decreased, means that the amplification effect of financial leverage in the short term is not very obvious, but it does not rule out that the company has taken some measures to reduce financial leverage. 
Table 1. BOSSCO's financial data [6] for 2015-2017 under DuPont analysis.

\begin{tabular}{cccc}
\hline & 2015 & 2016 & 2017 \\
\hline ROE (Rate of Return on Equity) & $13.11 \%$ & $11.84 \%$ & $13.78 \%$ \\
Net Profit Margin on Sales & $8.68 \%$ & $10.52 \%$ & $9.68 \%$ \\
Total Assets Turnover & 0.54 & 0.5 & 0.47 \\
EM (Equity Multiplier) & 2.82 & 2.25 & 3.03 \\
\hline
\end{tabular}

\section{Possible Impacts and Risks}

\subsection{Performance Impacts}

\subsubsection{Increasing Financing Channels for SMEs}

Green credit provides new financing channels for SMEs with financing difficulties and can gain more space for the development of SMEs. By obtaining green credit, companies can reduce their capital costs and get loans at lower interest rates, which is beneficial to developing themselves [7]. If the company that receives this financing can fully play the role of the fund and improve the company's sales and operation level, the company's performance will be improved to some extent.

\subsubsection{Encourage the Healthy Development of SMEs}

Providing green loans for enterprises is equivalent to encouraging enterprises to develop in a green and ecological direction from the source. In the development of some small and medium-sized enterprises, because of limited funds, in order to save costs as much as possible, there is no way to use particularly good raw materials and equipment, and there is no way to produce excellent products, which in turn cannot improve performance and form a vicious circle. When a company obtains credit, it is equivalent to having a fund, and it can achieve better development than before.

\subsection{Risks}

\subsubsection{Credit Repayment Risk}

The essence of green credit is the bank's credit loan, and there are conditions for repayment of principal and interest. The performance of SMEs is unstable and financing channels are limited. If the company is not operating properly and fails to repay the loan in time, in the absence of other sources of funds, the company will face a large risk of repayment, which may lead to the break of the capital chain. Moreover, some SMEs have limited ability to operate funds. If they fail to formulate effective use plans for loans, and bring benefits to enterprises, then this fund will also be a burden for enterprises.

\subsubsection{Risk of Renovation Required to Obtain a Loan}

In order to meet the national green credit requirements, enterprises must upgrade existing production equipment and production methods, or make some renovation. These investment inputs are usually non-profit. This increases the operating costs of the company and reduces profitability in the short term. The 
SMEs themselves have a tight capital chain, lacking other effective financing channels, and often no effective guarantees. Additional investment needs to increase the bank's financing quota, but it may exceed its own solvency and fall into a dilemma.

\subsubsection{Risk of Excessive Financial Leverage}

Credit belongs to the liability side in the balance sheet. If the green credit of enterprises increase, and the asset-liability ratio of enterprises will increase when other assets are relatively unchanged. According to the formula of the equity multiplier, the asset-liability ratio of the enterprise will increase, and the corresponding equity multiplier will also increase, thereby increasing the financial leverage of the enterprise and amplifying the operational risk.

\section{Conclusion}

Green credit is indeed a new financing channel for SMEs. However, there are still some imperfections in the construction of green credit, and enterprises may face some risks. BOSSCO's financial performance has not been too much problem after obtaining green credit, which is inseparable from its own strategic and financial planning. If SMEs do not formulate corresponding plans and countermeasures before and after obtaining green loans, not making reasonable use of funds, there is still a certain risk.

\section{Conflicts of Interest}

The author declares no conflicts of interest regarding the publication of this paper.

\section{References}

[1] Jcucken, M. (2001) Sustainable Financing and Banking: The Financial Sector and Future of the Planet. Earthscan Publication Ltd., London.

[2] Schaltegger, S. and Figge, F. (2000) Environental Shareholder Value: Economic Success with Corporate Environmental Management. Eco-Management and Auditing, 7, 29-42. https://doi.org/10.1002/(SICI)1099-0925(200003)7:1<29::AID-EMA119>3.0.CO;2-1

[3] Xu, L.H. (2014) Research on the Environmental Risk Management of Small and Medium-Size Enterprises under the Background of Green Credit. Ningbo University, Ningbo, 10-27.

[4] Duan, J. and Niu, M.Q. (2010) The Paradox of Green Credit in China. Energy Procedia, 5, 1979-1986.

[5] Lin, J. (2006) The British Government's Policy of Supporting the Development of Small and Medium Enterprises and Its Enlightenment. Contemporary Education and Culture, 10, 34-37.

[6] BOSSCO Environmental Protection Technology Co., Ltd. (2017) 2015-2017 BOSSCO Environmental Protection Technology Co., Ltd Annual Report. http://www.bossco.cc/investment.aspx

[7] Lian, L.L. (2015) Does Green Credit Influence Debt Financing Cost of Business? - A Comparative Study of Green Businesses and "Two High" Businesses. Journal of Finance and Economics, 5, 83-93. 